Article

\title{
Differences in Readability, Keywords, and Orientation of Mission Statements of the Top 100 Korean and Top 100 US Traditional and Innovative Companies
}

\author{
Jongdo Jeon ${ }^{1}$ and Keun Tae Cho ${ }^{1,2, *}$ \\ 1 Graduate School of Management of Technology, Sungkyunkwan University, Seoburo 2066, \\ Suwon 16419, Korea; jongdojeon@gmail.com \\ 2 Department of Systems Management Engineering, Sungkyunkwan University, Seoburo 2066, \\ Suwon 16419, Korea \\ * Correspondence: ktcho@skku.edu; Tel.: +82-031-290-7602
}

Citation: Jeon, J.; Cho, K.T.

Differences in Readability, Keywords, and Orientation of Mission

Statements of the Top 100 Korean and Top 100 US Traditional and Innovative Companies. Sustainability 2021, 13, 10220. https://doi.org/ $10.3390 /$ su131810220

Academic Editor: Fernando Almeida

Received: 19 August 2021

Accepted: 8 September 2021

Published: 13 September 2021

Publisher's Note: MDPI stays neutral with regard to jurisdictional claims in published maps and institutional affiliations.

Copyright: (c) 2021 by the authors. Licensee MDPI, Basel, Switzerland. This article is an open access article distributed under the terms and conditions of the Creative Commons Attribution (CC BY) license (https:// creativecommons.org/licenses/by/ $4.0 /)$.

\begin{abstract}
The mission statements of companies reflect the characteristics of their country. There are differences in the content of mission statements between traditional and innovative companies. The sustainable growth of companies has recently become a major focus, and it has been found that mission statements are somewhat related to company innovation. This study analyzed the differences in the readability, keywords, and orientation of mission statements between the top 100 Korean and top 100 US companies by market capitalization and their traditionality and innovativeness. Differences in readability were assessed with the Gunning fog index. Differences in the main keywords were assessed with a keyword network analysis. Differences in orientation were assessed with the nine components of a mission statement. As Korean companies were aiming for global business, there was not much difference in the readability of mission statements between Korean and US companies, but there was a difference between traditional and innovative companies in both countries. There was a difference in the keywords and orientation of the mission statements of Korean and US innovative companies. Both Korean and US innovative companies focused highly on "philosophy." However, Korean innovative companies focused more on "self-concept," and US innovative companies focused more on a "concern for survival."
\end{abstract}

Keywords: mission statement; keyword network analysis; text mining; innovation; Korean companies; US companies; readability; Gunning fog index; nine components of a mission statement; market capitalization

\section{Introduction}

Mission statements are widely considered necessary in helping a company form its identity, purpose, and direction [1]. Developing a mission statement is an important first step in the strategic planning process, expressing the reason for the company's existence and differentiating it from its competitors [2,3]. Drucker [4] stated that the existence of a company is determined by customers, and its purpose is to create customers, underscoring the need for a mission. Traditionally, mission statements are accepted as effective strategic management tools [5]. Therefore, a mission statement is the most fundamental tool for implementing a company's strategies and the achievement of its goals.

The sustainable growth of companies has recently become a major focus, and it has been found that mission statements are somewhat related to company innovation [6]. Innovation is a key element of performance, and an innovation-based perspective for competitive advantage leads to differentiated performance among companies [7]. Innovation DNA is integral in all aspects of a company's operations, including functional organization, which involves leadership, processes supporting innovative activities, and knowledge management and performance [8]. The scope of innovation is wide, from new product 
development to the creation of value in a new industry [8]. Lichtenthaler [9] found that companies such as Amazon, Apple, Alphabet, Netflix, Tesla, and Microsoft were ranked as the most innovative companies, according to various assessments. Their emphasis on artificial intelligence and digital platforms in the digital economy is becoming increasingly important in innovation [9]. According to The Wall Street Journal [10], the term "innovation" was used 33,000 times in the quarterly and annual reports of companies in 2011, and one-third of business schools in the United States used the term in their mission statements.

Mission statements have been examined in studies on various topics over the past few decades. According to Alegre et al. [11], mission statements were first studied in the 1980s, and it was found that a well-crafted mission statement can affect employees, organizational performance, and stakeholders. Various studies have been conducted on how mission statements vary among nations [12,13]. Bartkus et al. [12] analyzed the components of mission statements of European, Japanese, and US companies and studied their differences. Zhang et al. [6] comparatively analyzed the mission statements of Chinese and US companies included in the Fortune 500. Yadav and Sehgal [14] analyzed the mission statements of Indian companies based on the Forbes India 50. However, few studies have analyzed the mission statements of Korean companies and compared them with those of other countries. Therefore, this study comparatively analyzed the mission statements of the top 100 Korean and US companies by market capitalization.

There is a great difference in the market capitalization of Korean and US companies. The largest company in Korea by market capitalization is Samsung Electronics, with a market capitalization of USD 484 billion, which is only the 11th largest in the US market [15]. Conversely, Apple, the largest company in the United States by market capitalization, has a market capitalization of USD 2260 billion, which is greater than the total market capitalization of all the companies listed in the Korean market [15]. Due to this gap in market size, there may be some limitations in simply comparing Korean and US companies. However, according to the Bloomberg 2021 Innovation Index, Korea took first place with an innovation index of 90.49 , while the United States ranked 11th with an innovation index of 83.59 [16]. The Bloomberg 2021 Innovation Index rates the innovation capacity of 60 countries using seven metrics [16]. These include research and development intensity, manufacturing value added, productivity, high-tech density, tertiary efficiency, researcher concentration, and patent activity [16].

Despite the considerable difference in company market capitalization between Korean and US companies, Korea's innovation index is not lower than that of the United States. Therefore, the significance of this study is its analysis of the orientation of innovative companies among the top Korean and US companies by market capitalization. To select the subjects, the lists of the top 100 companies by market capitalization in Korea and the US were searched on investing.com, a website specializing in stock information [15]. Each company's mission statement was searched and summarized by accessing each website. For companies that did not specify mission statements, the vision statement or other similar statements were included with reference to expressions such as "purpose" or "what we do." Korean companies often use the term "management philosophy" instead of "mission," and thus this term was included in the analysis. Moreover, this study set the criteria for innovative companies, analyzed readability and keywords by company type, and comparatively analyzed mission statement orientation by classification and country.

Section 2 reviews and summarizes previous studies on mission statements, such as studies on the components of a mission statement, mission statements and corporate performance, different mission statements by nation, the readability of mission statements, and the correlation of high-tech firms and innovation with mission statements. Section 3 describes the study's data collection process, the analysis of readability, the extraction of the keywords through data processing, the analysis of keyword networks, and the examination of mission statement orientation based on the nine components of a mission statement. Section 4 summarizes the research methods and results for the re- 
search questions. Section 5 summarizes the results of this study and provides implications, discussions, and suggestions, and Section 6 presents the conclusions of this study.

\section{Literature Review}

\subsection{Studies on the Components of a Mission Statement}

Radke [17] claimed that a mission statement must be able to answer the following questions: (1) what are the opportunities or needs that we need to address (the purpose of the organization)? (2) what are we doing to address these needs (the business of the organization)? (3) what principles or beliefs guide our work (the values of the organization)? Bart [18] argued that a good mission statement must express the unique reason for the company's existence and make stakeholders aware that they are pursuing shared goals. In addition, a mission statement must have a convincing structure to answer tough questions such as "what is our business?"; "why do we exist?"; and "what are we trying to accomplish through the allocation of the company's resources?"

David [19] identified nine key components of a mission statement: (1) customers; (2) products or services; (3) markets; (4) technology; (5) concern for survival, growth, and profitability; (6) philosophy; (7) self-concept; (8) concern for public image; and (9) concern for employees. He also argued that communication about a clear business mission is often overlooked in strategic management and that a mission statement may change, but not often, if it is prepared with care. An organization's achievement can be increased by developing and communicating clear business missions for the company's existence. Rey and Bastons [20] suggested a holistic conceptualization of mission statements. According to the authors, a mission statement must consider three dimensions: (1) mission as a formal statement, (2) mission as a dynamic practice, and (3) mission as a source of motivation. Berbergal-Mirbent et al. [21] analyzed the mission statements of 39 social enterprises in Spain and the components of the mission statements that must be considered, especially in social enterprises, and observed a partial correlation between a firm's mission statement and its performance.

Kemp and Dwyer [22] examined the mission statements of 50 international airlines and mapped their components based on the nine components proposed by David [19]. The results showed that most mission statements of the 50 airlines included their self-concept $(88 \%)$, followed by their philosophy $(80 \%)$ and their customers (72\%) [22]. Lin et al. [23] analyzed the mission statements of 79 passenger airlines and compared the results with those of Kemp and Dwyer [22]. The study by Lin et al. [23] conducted in 2018 revealed that most of the mission statements included products/services (79.7\%), followed by customers $(68.8 \%)$ and location/markets (58.2\%), indicating that mission statements also change over time, in response to internal/external circumstances. Drucker [24] introduced the business management principles and strategies of non-profit organizations in his book Managing the Non-Profit Organization. Arias-Coello et al. [25] analyzed the mission statements of 47 public universities in Spain based on Drucker's mission statement components in non-profit organizations.

\subsection{Studies on the Correlation between Mission Statements and Corporate Performance}

Past research on the existence of a correlation between mission statements and corporate performance has shown conflicting results. Ireland and Hirc [26] suggested that mission statements can provide motivation and inspiration. Bart and Mark [27] argued that a mission statement is not automatically correlated with corporate performance; however, a mission statement that satisfies management has a positive correlation with corporate performance. Atrill et al. [28] studied the correlation between mission statement orientation and corporate performance of 143 listed companies in the United Kingdom. When companies in the service industries had shareholder orientation in the mission statements, there was a strong impact on their stock returns for three years, and those in the non-service industries also showed excess earnings in stock returns for six years. However, when 
the mission statements included customer orientation, there was little correlation with corporate performance.

\subsection{Studies on the Differences in Mission Statements among Countries}

Various studies have been conducted by different researchers on the differences in mission statements by country. Bartkus et al. [12] analyzed the components of mission statements of European, Japanese, and US companies and studied their differences. Their results showed that companies in these countries all mentioned customers and communicated about the future. The difference was that Japanese companies focused on motivating employees and on how to contribute to society, whereas US and European companies focused more on competitive advantage. This is because Japanese companies have a culture of emphasizing social values, while US companies tend to focus on the massive domestic market and believe that there is no point in expressing the market scope because they are already targeting the global market. Conversely, European companies try to express their geographical scope, mainly because of the many multinational companies based in Europe.

Zhang et al. [6] studied the mission statements of Chinese and US companies. They selected the top 100 companies included in the Fortune 500 and extracted and analyzed words through a corpus analysis. The results showed that the companies in the two countries shared similarities in terms of appraisal resources, but Chinese companies emphasized both innovation and the development of society and companies, whereas US companies stressed the importance of customers, products, and services. Both focused on survival, philosophy, and corporate image, and US companies showed more interest in stakeholders. Yadav and Sehgal [14] analyzed the mission statements of Indian companies. They classified the companies included in the Forbes India 50 as either manufacturing or service companies in an analysis of their mission statements. The results showed that Indian companies focused on customers as their main stakeholders, and the difference between manufacturing and service companies was not significant.

\subsection{Studies on the Readability of Mission Statements}

The readability of mission statements has also been analyzed in various studies. Rajasekar [5] assessed the readability of mission statements using the Gunning fog index (GFI) [29] to determine whether the nine components of a mission statement were present in the mission statements of 45 companies in Oman. The author found that the mission statements of companies in the financial sector had a readability index of 7.5 to 9 , whereas those in other sectors had an index exceeding 10.5, indicating the need for improvement. Yadav and Sehgal [14] also assessed the readability of mission statements of Indian companies. In that study, the index of manufacturing companies was 32.22, and that of service companies was 27.45 , showing that the readability of Indian companies' mission statements was low overall and needed improvement. Khan et al. [30] analyzed the readability of 197 Asian companies included in the Global Fortune 500 in 2014-2015. The results showed that the mission statements of most Asian companies were long and had low readability.

Research has also been conducted on the relationship between readability and the performance of mission statements. Cortes et al. [31] examined the mission statements of the top 248 universities in the world in 2013 and analyzed their readability using the GFI. The results showed that the average index was 20.82 and the distribution was 1.2 to 142.8. The difference was not significant by region or university size. However, analysis of the correlation between the GFI and the university rankings as the independent variable showed that lower GFI values indicated higher rankings. Cortes-Sanchez and Rivera [32] conducted a study on the readability of mission statements and the financial performance of Latin American companies. The results showed that there was a positive correlation between the readability of mission statements and return on assets. Li [33] studied the relationship between the readability of annual reports and corporate performance and found that more readable annual reports showed more positive earnings. 


\subsection{Mission Statements, High-Tech Firms, and Innovation}

Studies have also been conducted on mission statements of high-tech firms, which are the key source of innovation in companies. According to Bart [34], high-tech firms explained the "definition of success" relatively more often than others. In contrast, low-tech firms provided a broad definition of "core business." Another study by Bart [35] revealed that employee values and understanding of innovation were not attained automatically. The results of that study indicated that the key success factor of innovation is to effectively deliver the components of mission statements to members and to demonstrate commitment. Covin and Prescott [36] discovered that high-tech companies showed a stronger desire for market share growth and product innovation than low-tech companies in terms of mission strategies.

\subsection{Studies on the Keywords in Mission Statements}

Research on the keywords in mission statements has been conducted in various industrial sectors. Most of the recent studies have been on mission statements of universities. Bayrak [37] analyzed the keywords in the mission statements of the top 227 universities in Europe, Asia, South America, Africa, and North America and examined the similarities and differences of universities among the geographic areas. Guimarães et al. [38] analyzed the keywords in mission statements to determine how internationalization is expressed by federal universities in Brazil.

Case analyses on keywords and networks of mission statements in the tourism and aviation industries have also been conducted. Law and Breznik [39] analyzed the keywords in mission statements of 100 top-tier airlines, according to Skytrax, and conducted a network analysis. Some of the main keywords derived in the study were "service," "airline," "customer," "best," and "safety," and there was a focus on Asia-Pacific and European airlines. They also conducted a network analysis, revealing that the contents of mission statements can be classified into six islands [39]. Six islands were "tourism," "excellence," "transport and continuity," "embrace," "low fare," and "growth" [39]. Penco et al. [40] analyzed the keywords in the mission statements of 44 cruise lines and assessed their orientation toward stakeholders in the mission statements.

\section{Materials and Methods}

Figure 1 presents an overview of the research procedures and methods of the study. First, the lists of the top 100 Korean and top 100 US companies by market capitalization were identified. Next, their mission statements were accessed through their websites. Then innovative companies were classified separately. After classifying the innovative companies, the readability of mission statements was analyzed. We conducted a t-test to determine the differences regarding readability, and the top 30 keywords were extracted through text preprocessing. Then, the nine components of a mission statement and keywords were mapped and converted to one-mode matrices. Finally, eigenvector centrality was analyzed to summarize the differences in the orientations of Korean and US companies by utilizing a social network analysis method.

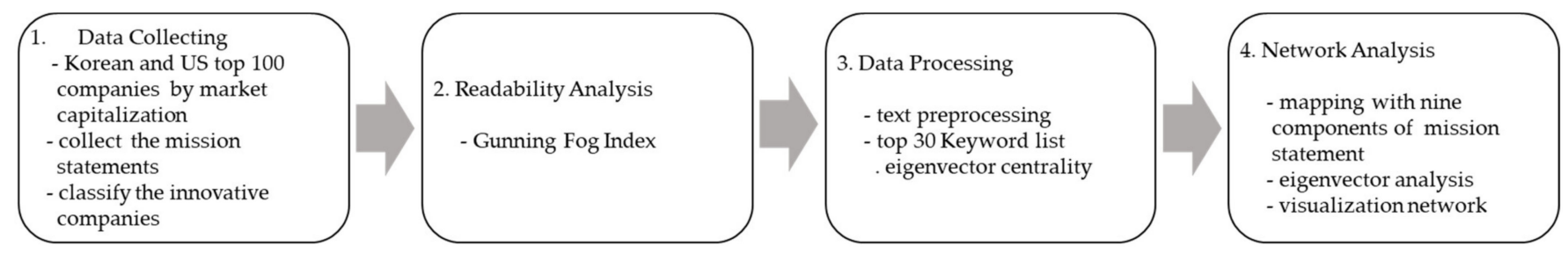

Figure 1. Research procedure and methods.

This study's research topics are presented in Table 1. 
1. To analyze the differences in readability of the mission statements of Korean and US companies, this study compared the readability of the top 100 Korean and top 100 US companies by market capitalization and the innovative and traditional companies of the two.

2. To compare the differences in keywords in the mission statements of Korean and US companies, 1st keyword network analysis was performed on the three groups.

3. To analyze the differences in the orientation of the mission statements of Korean and US companies, this study mapped the top 30 keywords of each group and the nine components of a mission statement proposed by David [19] and conducted a network analysis to determine the differences in orientation among groups.

Table 1. Research topics of the study.

\begin{tabular}{|c|c|c|c|}
\hline Category & Subcategory & Topic & Content Analysis \\
\hline 1 & $1-\mathrm{a}$ & $\begin{array}{l}\text { Comparison of } \\
\text { readability }\end{array}$ & $\begin{array}{l}\text { Comparison of the top } 100 \text { Korean and top } \\
100 \text { US companies }\end{array}$ \\
\hline 1 & $1-b$ & $\begin{array}{l}\text { Comparison of } \\
\text { readability }\end{array}$ & $\begin{array}{l}\text { Comparison of Korean traditional } \\
\text { companies and US traditional companies }\end{array}$ \\
\hline 1 & $1-\mathrm{c}$ & $\begin{array}{l}\text { Comparison of } \\
\text { readability }\end{array}$ & $\begin{array}{l}\text { Comparison of Korean innovative } \\
\text { companies and US innovative companies }\end{array}$ \\
\hline 2 & $2-a$ & Keyword analysis & $\begin{array}{l}\text { Comparison of the top } 100 \text { Korean and top } \\
100 \text { US companies }\end{array}$ \\
\hline 2 & $2-b$ & Keyword analysis & $\begin{array}{l}\text { Comparison of Korean traditional } \\
\text { companies and US traditional companies }\end{array}$ \\
\hline 2 & $2-c$ & Keyword analysis & $\begin{array}{l}\text { Comparison of Korean innovative } \\
\text { companies and US innovative companies }\end{array}$ \\
\hline 3 & 3-a & $\begin{array}{l}\text { Nine components of a } \\
\text { mission statement }\end{array}$ & $\begin{array}{l}\text { Comparison of the top } 100 \text { Korean and top } \\
100 \text { US companies }\end{array}$ \\
\hline 3 & $3-b$ & $\begin{array}{l}\text { Nine components of a } \\
\text { mission statement }\end{array}$ & $\begin{array}{l}\text { Comparison of Korean traditional } \\
\text { companies and US traditional companies }\end{array}$ \\
\hline 3 & $3-c$ & $\begin{array}{l}\text { Nine components of a } \\
\text { mission statement }\end{array}$ & $\begin{array}{l}\text { Comparison of Korean innovative } \\
\text { companies and US innovative companies }\end{array}$ \\
\hline
\end{tabular}

\subsection{Data Collection}

The subjects of this study were the top 100 Korean and top 100 US companies by market capitalization. The list of companies was found on Investing.com, an online financial market platform. Investing.com [15] provides real-time data, market prices, charts, and the latest news on 250 stock exchanges, with 46 million monthly net visitors. This study accessed the list of the top 100 companies by market capitalization based on ordinary shares among companies listed in the Korean and US stock markets as of 20 April 2021, on Investing.com. Korean-listed companies were based in Korea, and US-listed companies were based in the United States.

The largest Korean company by market capitalization was Samsung Electronics (129, Samsung-ro, Yeongtong-gu, Suwon-si, Gyeonggi-do, Republic of Korea), with a market capitalization of USD 484 billion. SK Hynix (2091, Gyeongchung-daero, Bubal-eup, Icheon-si, Gyeonggi-do, Republic of Korea), Naver (6, Buljeong-ro 65beon-gil, Bundang-gu, Seongnam-si, Gyeonggi-do, Republic of Korea), LG Chem (66, Yeoui-daero, Yeongdeungpogu, Seoul, Republic of Korea, Hyundai Motor Company (12, Heolleung-ro, Seocho-gu, Seoul, Republic of Korea), Samsung Biologics (300, Songdo bio-daero, Yeonsu-gu, Incheon, Republic of Korea), Kakao (242, Cheomdan-ro, Jeju-si, Jeju-do, 63309, Republic of Korea), Samsung SDI (150-20, Gongse-ro Giheung-gu, Yongin-si, Gyeonggi-do, Republic of Korea), and Celltrion (23, Academy-ro, Yeonsu-gu, Incheon, Republic of Korea) were also included in the top 10 companies [15]. In terms of industry, $10 \%$ were in the biotech industry (10 companies), followed by $7 \%$ in the chemical industry, 6\% in computer services, 5\% in electronic equipment, and 5\% in investment services, showing that biotech companies account for the largest share [15]. The largest US company by market capitalization was Apple (1 infinite Loop City. Cupertino, CA, USA), with a market capitalization of USD 
2260 billion. Microsoft (One Microsoft Way. Redmond, WA, USA), Amazon (440 Terry Avenue North Seattle, WA, USA), Alphabet (1600 Amphitheater Parkway. Mountain View, CA, USA), Facebook (1 Hacker Way. Menlo Park, CA, USA), Tesla (3500 Deer Creek Road. Palo Alto, CA, USA), Berkshire Hathaway (3555 Farnam Street. Omaha, NE, USA), JPMorgan Chase (270 Park Avenue. New York, NY, USA), Visa (One Market Plaza. San Francisco, CA, USA), and Johnson \& Johnson (One Johnson \& Johnson Plaza. New Brunswick, NJ, USA) were also included in the top 10 companies [15]. In terms of industry, 9\% were in the software industry (9 companies), followed by $9 \%$ in retail, $8 \%$ in the biotech industry, $7 \%$ in computer services, and $6 \%$ in the semiconductor business. Many US companies were technology-based service companies, whereas Korean companies showed a high share of traditional industries, aside from the biotech industry [15].

To analyze the characteristics of the innovative company group, this study classified 21 Korean companies (see Table 2) and 34 US companies (see Table 3) as innovative companies based on the list of innovative companies announced by various institutions. The Boston Consulting Group [41] selects and announces innovative companies every year by surveying companies that are best preparing for five key elements: (1) setting a clear ambition, (2) establishing the right playing fields, (3) prioritizing performance management, (4) pushing project management, and (5) developing talent and culture. Forbes [42] assessed the present and future innovation skills of companies and selected the world's most innovative companies in 2018 and posted them on their websites. Forbes excludes sectors in which investment in research and development cannot be measured, such as financial services and traditional companies related to raw material prices, rather than innovation such as energy and mining.

Table 2. Innovative companies among the top 100 Korean companies.

\begin{tabular}{|c|c|c|c|c|c|}
\hline No. & Company Name & Selected by & No. & Company Name & Selected by \\
\hline 1 & $\begin{array}{l}\text { Samsung } \\
\text { Electronics }\end{array}$ & BCG & 12 & Hyundai Mobis & Fnguide \\
\hline 2 & SK hynix & Fnguide & 13 & $\begin{array}{l}\text { LG Household \& } \\
\text { Health Care }\end{array}$ & Forbes \\
\hline 3 & Naver & Forbes & 14 & SK Innovation & KRX \\
\hline 4 & LG Chem & Fnguide & 15 & SK telecom & Clarivate \\
\hline 5 & $\begin{array}{l}\text { Hyundai Motor } \\
\text { Company }\end{array}$ & BCG & 16 & LG & BCG \\
\hline 6 & Samsung Biologics & KRX & 17 & NCSOFT & KRX \\
\hline 7 & Kakao & Fnguide & 18 & Amorepacific & Forbes \\
\hline 8 & Samsung SDI & Fnguide & 19 & Netmarble & $\mathrm{KRX}$ \\
\hline 9 & Celltrion & Forbes & 20 & $\begin{array}{c}\text { SK } \\
\text { Biopharmaceuticals }\end{array}$ & $\mathrm{KRX}$ \\
\hline 10 & Kia & Fnguide & 21 & Kakao Games & $\mathrm{KRX}$ \\
\hline 11 & LG Electronics & Clarivate & & & \\
\hline
\end{tabular}

BCG = Boston Consulting Group; KRX = Korea Exchange.

Table 3. Innovative companies among the top 100 US companies.

\begin{tabular}{cccccc}
\hline No. & Company Name & Selected by & No. & Company Name & Selected by \\
\hline 1 & Apple & BCG & 18 & Abbott Laboratories & BCG \\
2 & Microsoft & BCG & 19 & Pfizer & BCG \\
3 & Amazon & BCG & 20 & Salesforce.com & BCG \\
4 & Alphabet & BCG & 21 & Nike & BCG \\
5 & Facebook & BCG & 22 & Pepsico & BCG \\
6 & Tesla & BCG & 23 & Merck \& Co. & BCG \\
7 & Visa & Forbes & 24 & SAP & BCG \\
8 & Johnson \& Johnson & BCG & 25 & United Parcel Service & Forbes \\
\hline
\end{tabular}


Table 3. Cont.

\begin{tabular}{cccccc}
\hline No. & Company Name & Selected by & No. & Company Name & Selected by \\
\hline 9 & Walmart & BCG & 26 & Starbucks & Forbes \\
10 & Walt Disney & BCG & 27 & International Business & BCG \\
11 & Procter \& Gamble & BCG & 28 & Machines & General Electric \\
12 & Comcast & BCG & 29 & Estée Lauder & Forbes \\
13 & Adobe Systems & Forbes & 30 & Intuit & Forbes \\
14 & Netflix & Forbes & 31 & ServiceNow & Forbes \\
15 & Coca-Cola & BCG & 32 & Target & BCG \\
16 & Oracle & BCG & 33 & Booking Holdings & Forbes \\
17 & Cisco & BCG & 34 & Intuitive Surgical & Forbes \\
\hline BCG
\end{tabular}

$\overline{\mathrm{BCG}}=$ Boston Consulting Group.

There were only seven Korean companies among the innovative companies selected by the Boston Consulting Group and Forbes; thus, the scope was expanded to other institutions. Clarivate [43] has announced the top 100 global innovative companies every year since 2011 by analyzing the patents of global institutions; Korean companies on this list were included in the innovative companies of this study. In addition, those belonging to the K-innovation index announced by Fnguide [44], founded in 2000 and providing financial information on Korean companies, were also included. The representative items in the K-New Deal Index [45] by the Korea Exchange were also included.

After organizing the list of the top 100 Korean and 100 US companies by market capitalization and classifying the innovative companies, the mission statements of those companies were obtained. Those that did not belong to innovative companies among the top 100 companies of both countries were classified as belonging to traditional companies. The mission statements were accessed online by visiting the companies' websites. The English websites of the Korean companies were used to examine the English version of the mission statement. Some Korean companies did not have clear mission statements, in which case their management philosophy was applied. If the management philosophy was unclear, their vision or goals were used. More US companies had mission statements than Korean companies; however, in cases where there was no clear mission statement, similar text that could serve as a mission statement was used, such as text with terms and phrases such as "purpose" and "what we are doing."

\subsection{Readability Analysis}

The GFI tool was used to test the readability of the mission statements of Korean and US companies (http:/ /gunning-fog-index.com, accessed on 22 April 2021). The index value is an Arabic numeral. Sentences scoring 6 points are sentences that can be understood by sixth-grade students, and those scoring 13 points can be understood by college freshmen. There are various readability tools, such as the Flesch Reading Ease Score, the SMOG Index, and the Coleman-Liau index, but the GFI [29] is the most widely used to test readability. The subjects of the readability analysis are shown in Table 4, and a comparative analysis was conducted between the top 100 Korean and 100 US companies, Korean and US traditional companies, and Korean and US innovative companies.

Table 4. Number of Korean and US companies included in the study.

\begin{tabular}{ccc}
\hline Classification & Korea $(\boldsymbol{n})$ & United States $(\boldsymbol{n})$ \\
\hline Top 100 companies & 100 & 100 \\
Traditional companies & 79 & 66 \\
Innovative companies & 21 & 34 \\
\hline
\end{tabular}




\subsection{Data Preprocessing}

Text mining was used to analyze the data in text form, and $\mathrm{R}$ version 4.0.5 ( $\mathrm{R}$ Foundation for Statistical Computing, Vienna, Austria) was used as a data-mining tool. The " $\mathrm{tm}$ " package included in $\mathrm{R}$ was used to process the unstructured strings [46]. The mission statements of sample companies in Korea and the United States saved on the Microsoft Excel sheet (Redmond, WA, USA) were converted to a comma-separated values file and turned into a corpus on $\mathrm{R}$. This required text preprocessing, the elimination of all gaps, and the conversion of all letters to lower case because the capital and lower-case letters are considered the same words. Moreover, meaningless articles, prepositions, or words that would have no impact on the analysis (e.g., our, but, will, and, all, for, purpose) were excluded, and, afterward, the keywords and frequency were extracted. The keywords were extracted by classifying the subjects into the top 100 companies, traditional companies, and innovative companies, for both countries, as done in the readability analysis.

\subsection{First Mission Statement Keyword Network Analysis}

A social network analysis was conducted based on the keywords extracted using Gephi 0.9.2 [47]. Network analysis has the advantage of clearly defining and structuring the relationships among keywords in a network [48]. It is also referred to as language network analysis because the text in words is the subject of analysis [49]. By finding various concepts with high network centrality through network analysis, it is possible to understand the intention of the overall text [49]. Keywords become nodes of the language network, and the relationships among keywords become links [49]. The basic centrality indices in a network are degree centrality, betweenness centrality, closeness centrality, and eigenvector centrality $[50,51]$.

Degree centrality focuses on the connection with other nodes, measured by the number of other points connected to one point. More connections indicate greater influence. Betweenness centrality measures how well a node performs a mediating role in forming a network with other nodes. Closeness centrality refers to how close one point is to another point, and the distance between two points is key [50]. Eigenvector centrality reflects the centrality of other nodes connected to specific nodes on the weighted value, and nodes with high eigenvector centrality indicate that the other nodes are connected to many important nodes in the network. In other words, a higher eigenvector centrality indicates a higher influence of the node [51]. This study extracted keywords from each group based on eigenvector centrality, which can determine the nodes that have a high influence.

\subsection{Mapping of the Nine Components of a Mission Statement}

Through the first network analysis, 30 keywords were extracted for each of the top 100 Korean companies, top 100 US companies, Korean traditional companies, US traditional companies, Korean innovative companies, and US innovative companies based on eigenvector centrality. A second mapping was done based on the extracted keywords with the nine components of a mission statement proposed by David as shown in Table 5 [19]: (1) customers; (2) products or services; (3) markets; (4) technology; (5) concern for survival, growth, and profitability; (6) philosophy; (7) self-concept; (8) concern for public image; and (9) concern for employees. The three elements that were most correlated per keyword were matched. 
Table 5. Nine components of a mission statement.

\begin{tabular}{ccc}
\hline No. & Component & Remark \\
\hline A & Customers & Who are the enterprise's customers? \\
B & Products or services & What are the firm's major products or services? \\
C & Markets & Where does the firm compete? \\
D & Technology & What is the firm's basic technology? \\
E & Concern for survival, growth, & What is the firm's commitment to \\
and profitability & economic objectives? \\
G & Philosophy & What are the basic beliefs, core values, aspirations, \\
H & Self-concept & and philosophical priorities of the firm? \\
I & Concern for public image & What are the firm's major strengths and \\
& Concern for employees & competitive advantages? \\
& & What is the firm's public image? \\
\hline
\end{tabular}

Adapted from David [19].

\subsection{Second Network Analysis}

The purpose of this study was to identify which of the nine components of the mission statements of Korean and US companies are related and which element has the highest influence and to examine the differences through network analysis. Therefore, the second network analysis was conducted by converting the nine components and the two-mode matrix of the mapped keywords into a one-mode matrix. For conversion, the MMULT and TRANSEPOSE functions provided by Microsoft Excel were used [52]. Then to analyze influential nodes, the orientation of each group's mission statement was analyzed based on eigenvector centrality, as done in the first network analysis.

\section{Results}

\subsection{Readability Analysis}

This study obtained the mission statements of the top 100 Korean and top 100 US companies and analyzed the differences in the readability of the mission statements of the two groups and their traditional and innovative subgroups using the GFI. The results are shown in Table 6. There were no significant differences among the samples in terms of mission statement readability. The average GFI for the top 100 Korean companies was 15.7 , and there was a distribution of 33.33 at 2. The average index value for the top 100 US companies was 15.3, and there was a distribution of 31.3 at 2 , showing no significant difference in the readability of mission statements between the two groups. The GFI for Korean traditional companies was 16.2, and there was a distribution of 33.3 at 2. The GFI for US traditional companies was 16.5, and there was a distribution of 31.27 at 3.2, showing similar values between the two groups. There was also no significant difference in the readability of mission statements between Korean and US innovative companies. The GFI for Korean innovative companies was 13.5, and there was a distribution of 21.27 at 3.2. The GFI for US innovative companies was 12.9, and there was a distribution of 24.1 at 2, showing no significant difference between the two groups.

Table 6. Results of the analysis of Gunning fog indexes of mission statements of Korean and US companies.

\begin{tabular}{|c|c|c|c|c|c|c|c|c|}
\hline Item & $\begin{array}{l}\text { Top } 100 \\
\text { Korean }\end{array}$ & Top 100 US & Item & $\begin{array}{c}\text { Korean } \\
\text { Traditional }\end{array}$ & $\begin{array}{c}\text { US } \\
\text { Traditional }\end{array}$ & Item & $\begin{array}{c}\text { Korean } \\
\text { Innovative }\end{array}$ & $\begin{array}{c}\text { US } \\
\text { Innovative }\end{array}$ \\
\hline Mean & 15.65074 & 15.3049 & Mean & 16.218772 & 16.531091 & Mean & 13.513857 & 12.924647 \\
\hline Median & 15.52 & 14.8 & Median & 16.21 & 15.655 & Median & 13.9 & 13.55 \\
\hline Minimum & 2 & 2 & Minimum & 2 & 3.2 & Minimum & 3.2 & 2 \\
\hline Maximum & 33.33 & 31.27 & Maximum & 33.33 & 31.27 & Maximum & 21.27 & 24.05 \\
\hline $\operatorname{Parameter}(n)$ & 100 & 100 & $\operatorname{Parameter}(n)$ & 79 & 66 & $\operatorname{Parameter}(n)$ & 21 & 34 \\
\hline$t^{*}$ & \multirow{2}{*}{\multicolumn{2}{|c|}{$\begin{array}{l}0.397 \\
0.691\end{array}$}} & $t^{*}$ & \multirow{2}{*}{\multicolumn{2}{|c|}{$\begin{array}{c}-0.291 \\
0.772\end{array}$}} & $t^{*}$ & \multirow{2}{*}{\multicolumn{2}{|c|}{$\begin{array}{l}0.455 \\
0.651\end{array}$}} \\
\hline$p$ & & & $p$ & & & $p$ & & \\
\hline
\end{tabular}


There were no significant differences in the GFI between Korean and US companies, but the GFI differences among groups within the country are as shown in Figure 2 and Table 7. The GFI of Korean traditional companies was 16.2 and that of innovative companies was 15.5. The GFI of US traditional companies was 16.5 and that of innovative companies GFI was 12.9 .

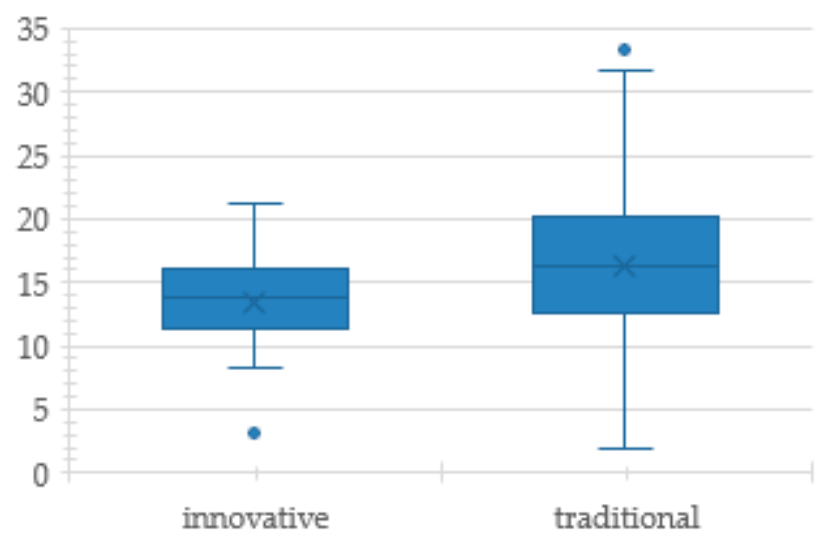

(a)

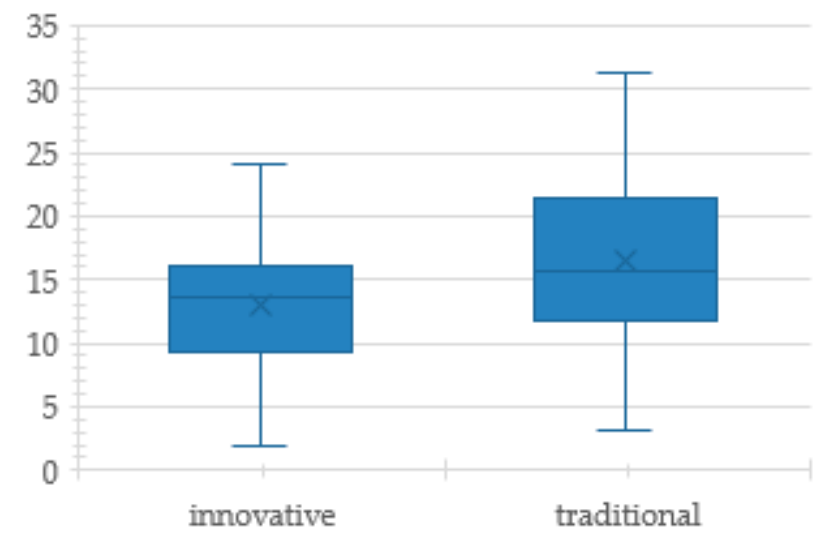

(b)

Figure 2. Differences in Gunning fog index (GFI) between traditional and innovative companies of each country. (a) Comparison of GFI of Korean innovative and traditional companies; (b) Comparison of GFI of US innovative and traditional companies.

Table 7. Differences in Gunning fog index between traditional and innovative companies of each country.

\begin{tabular}{|c|c|c|c|c|c|}
\hline Item & $\begin{array}{c}\text { Korean } \\
\text { Traditional }\end{array}$ & $\begin{array}{c}\text { Korean } \\
\text { Innovative }\end{array}$ & Item & US Traditional & US Innovative \\
\hline Mean & 16.218772 & 13.513857 & Mean & 16.531091 & 12.924647 \\
\hline Median & 16.21 & 13.9 & Median & 15.655 & 13.55 \\
\hline Minimum & 2 & 3.2 & Minimum & 3.2 & 2 \\
\hline Maximum & 33.33 & 21.27 & Maximum & 31.27 & 24.05 \\
\hline $\operatorname{Parameter}(n)$ & 79 & 21 & Parameter $(n)$ & 66 & 34 \\
\hline$t^{*}$ & \multicolumn{2}{|c|}{2.275} & $t^{*}$ & \multicolumn{2}{|c|}{3.062} \\
\hline$p$ & \multicolumn{2}{|c|}{0.027} & $p$ & \multicolumn{2}{|c|}{0.003} \\
\hline
\end{tabular}

$* p<0.05$.

The fact that the average GFI for the top 100 Korean and top 100 US companies exceeds 15 indicates that the readability of mission statements is low, and the sample groups must use words and sentences that are easier to understand. There was no difference in the readability of mission statements between Korean and US companies, but a difference in readability between traditional companies and innovative companies was found in both Korea and the United States. The GFI for Korean traditional companies and US traditional companies was 16, but for Korean innovative companies the GFI was 13.5 and for US innovative companies the GFI was 12.9, showing that the GFI for innovative companies was low in both countries. This indicates that the mission statements of innovative companies are relatively more concise and readable than those of traditional companies. The difference was also found in the comparison of the median and maximum of the traditional company subgroups and the innovative company subgroups. The median for Korean and US traditional companies was 16.2 and 15.7, respectively, but the median for Korean and US innovative companies was 13.9 and 13.6, respectively. The maximum GFI for Korean and US traditional companies was 33.3 and 31.3, respectively. The maximum GFI for Korean and US innovative companies was 21.3 and 24.1, respectively. 


\subsection{First Mission Statement Keyword Network Analysis}

This study extracted keywords from the mission statements of the top 100 Korean and top 100 US companies through text preprocessing by group and classified the top 30 keywords based on eigenvector centrality on Gephi. The top 30 keywords of the top 100 Korean and top 100 US companies, Korean traditional companies, US traditional companies, Korean innovative companies, and US innovative companies are shown in Tables 8 and 9. The keywords in a red font color are those that were duplicated among the 30 keywords between groups. There were 12 redundant keywords from the mission statements of the top 100 Korean and top 100 US companies and 10 redundant keywords from the mission statements of Korean and US traditional companies. There were six redundant keywords in the mission statements of Korean and US innovative companies, showing the lowest redundancy.

The top keywords of the top 100 Korean companies were "value," "company," "global," "customer," "lead," and "technology," indicating that they sought to become global leaders who provide value to customers. The top keywords of the top 100 US companies were "world," "customer," "people," "life," "innovation," and "improve," indicating that they intended to support innovative living among customers throughout the world. In addition, the top 100 Korean companies used the word "global" to reflect their will to expand overseas, in their mission statements, but the top 100 US companies used the word "world," indicating that they already viewed themselves as main operators in the global market.

The top keywords of Korean traditional companies were "value," "company," "global," "customer," "lead," and "growth," which were not very different from those of the top 100 Korean companies. The top keywords of US traditional companies were "world," "customer," "life," "innovation," "people," and "service," which also did not show much difference from those of the top 100 US companies. However, "growth" was higher in the ranks of Korean traditional companies than the top 100 Korean companies, while "innovation" was higher in the ranks of US traditional companies than the top 100 US companies. This implies that Korean traditional companies are expressing their pursuit of becoming a global leader that provides value to customers as well as growth in their mission statements. Traditional companies in the US reflected the goal of providing innovative life and service for customers and people of the world.

The top keywords of Korean innovative companies were "create," "future," "dream," "technology," "human," and "life," which were different from those of the top 100 Korean companies and Korean traditional companies. The top keywords of US innovative companies were "world," "people," "life," "company," "improve," and "innovation," which were similar to those of the top 100 US companies and US traditional companies. Therefore, there was a difference in keywords between the Korean and US innovative companies. Korean innovative companies aimed to fulfill dreams about the future using creativity based on technology and focusing on humans. US innovative companies aimed to improve people's lives and to provide innovation, which was similar to the top 100 US companies and US traditional companies. This indicates that Korean innovative companies focused more on the future and creativity based on "technology." US innovative companies had top keywords that were similar to those of US traditional companies because the top $100 \mathrm{com}$ panies by market capitalization in the US are already carrying out new developments in the market and focusing constantly on innovation.

\subsection{Mapping of the Nine Components of a Mission Statement}

The nine components of the mission statements were mapped using the keywords in Tables 8 and 9. Because the keywords could be included in multiple components, redundancy was allowed, and up to three items were mapped in the order of the highest correlation. The components related to the keywords were marked as 1, and the others were marked as 0 . The results of mapping the keywords and nine components of each group are shown in Tables A1-A6 in the Appendix A. The two-mode matrix was converted 
to a one-mode matrix using the MMULT and TRANSEPOSE functions in Microsoft Excel, after which a second network analysis was conducted [52].

Table 8. Top 30 keywords of top 100 Korean companies and Korean traditional companies and their eigenvector centrality.

\begin{tabular}{|c|c|c|c|c|c|c|c|c|}
\hline No. & $\begin{array}{l}\text { Top } 100 \\
\text { Korean }\end{array}$ & $\begin{array}{l}\text { Eigenvector } \\
\text { Centrality }\end{array}$ & Top 100 US & $\begin{array}{l}\text { Eigenvector } \\
\text { Centrality }\end{array}$ & $\begin{array}{c}\text { Korean } \\
\text { Traditional }\end{array}$ & $\begin{array}{l}\text { Eigenvector } \\
\text { Centrality }\end{array}$ & $\begin{array}{c}\text { Korean } \\
\text { Traditional }\end{array}$ & $\begin{array}{c}\text { Eigenvector } \\
\text { Centrality }\end{array}$ \\
\hline 1 & value & world & 1 & value & 1 & world & 1 & world \\
\hline 2 & company & customer & 0.774151 & company & 0.931142 & customer & 0.850277 & customer \\
\hline 3 & global & people & 0.719219 & global & 0.878196 & life & 0.69572 & people \\
\hline 4 & customer & life & 0.710223 & customer & 0.86798 & innovation & 0.682377 & life \\
\hline 5 & lead & innovation & 0.661259 & lead & 0.786831 & people & 0.673454 & innovation \\
\hline 6 & technology & improve & 0.576977 & growth & 0.643617 & service & 0.571936 & improve \\
\hline 7 & life & company & 0.575527 & business & 0.584263 & way & 0.569086 & company \\
\hline 8 & growth & service & 0.524781 & life & 0.581995 & company & 0.53176 & service \\
\hline 9 & create & create & 0.496163 & technology & 0.573876 & business & 0.504897 & create \\
\hline 10 & society & technology & 0.484071 & create & 0.571965 & improve & 0.478547 & technology \\
\hline 11 & contribute & way & 0.453874 & contribute & 0.54685 & advance & 0.468613 & way \\
\hline 12 & business & finance & 0.428869 & service & 0.543184 & finance & 0.463728 & finance \\
\hline 13 & trust & advance & 0.412822 & develop & 0.515115 & solution & 0.455339 & advance \\
\hline 14 & develop & value & 0.400019 & industry & 0.51298 & live & 0.448551 & value \\
\hline 15 & service & business & 0.399659 & trust & 0.510865 & create & 0.443241 & business \\
\hline 16 & product & product & 0.388831 & continue & 0.507545 & technology & 0.438427 & product \\
\hline 17 & future & community & 0.386283 & product & 0.488863 & growth & 0.43143 & community \\
\hline 18 & industry & growth & 0.368142 & society & 0.488675 & human & 0.420601 & growth \\
\hline 19 & continue & solution & 0.364818 & social & 0.468126 & community & 0.42003 & solution \\
\hline 20 & social & economy & 0.360561 & ecofriendly & 0.463571 & together & 0.41102 & economy \\
\hline 21 & responsibility & live & 0.350113 & corporate & 0.456112 & lead & 0.408106 & live \\
\hline 22 & corporate & connect & 0.347027 & management & 0.448593 & communicate & 0.408017 & connect \\
\hline 23 & ecofriendly & time & 0.339474 & energy & 0.415462 & challenge & 0.399657 & time \\
\hline 24 & human & invest & 0.334142 & sustainable & 0.411197 & better & 0.391779 & invest \\
\hline 25 & management & challenge & 0.33237 & future & 0.401524 & solve & 0.367838 & challenge \\
\hline 26 & happy & together & 0.330624 & community & 0.389077 & full & 0.359005 & together \\
\hline 27 & energy & human & 0.329794 & local & 0.384946 & range & 0.359005 & human \\
\hline 28 & sustainable & experience & 0.326942 & responsibility & 0.383701 & connect & 0.355574 & experience \\
\hline 29 & community & better & 0.324973 & competitive & 0.366742 & economy & 0.353618 & better \\
\hline 30 & local & empower & 0.422212 & high & 0.365925 & science & 0.349951 & empower \\
\hline
\end{tabular}

The keywords in red are those that were duplicated among the 30 keywords between groups.

Table 9. Top 30 keywords of Korean and US innovative companies and their eigenvector centrality.

\begin{tabular}{ccccc}
\hline No. & $\begin{array}{c}\text { Korean } \\
\text { Innovative }\end{array}$ & $\begin{array}{c}\text { Eigenvector } \\
\text { Centrality }\end{array}$ & US Innovative & $\begin{array}{c}\text { Eigenvector } \\
\text { Centrality }\end{array}$ \\
\hline 1 & create & 1 & world & 1 \\
2 & future & 0.851098 & people & 0.91147 \\
3 & dream & 0.747483 & life & 0.865913 \\
4 & technology & 0.660424 & company & 0.806375 \\
5 & human & 0.643811 & improve & 0.744491 \\
6 & life & 0.607498 & innovation & 0.640568 \\
7 & realize & 0.550081 & brand & 0.619302 \\
8 & thinking & 0.550081 & thing & 0.586024 \\
9 & challenge & 0.514471 & create & 0.585071 \\
10 & mankind & 0.514471 & power & 0.573913 \\
11 & world & 0.50193 & opportunity & 0.539683 \\
12 & building & 0.496529 & customer & 0.49097 \\
13 & possibility & 0.496529 & entertain & 0.487792 \\
14 & responsibility & 0.496529 & technology & 0.487792 \\
15 & sense & 0.496529 & inspire & 0.481389 \\
16 & tackling & 0.496529 & value & 0.43574 \\
\hline
\end{tabular}


Table 9. Cont.

\begin{tabular}{ccccc}
\hline No. & $\begin{array}{c}\text { Korean } \\
\text { Innovative }\end{array}$ & $\begin{array}{c}\text { Eigenvector } \\
\text { Centrality }\end{array}$ & US Innovative & $\begin{array}{c}\text { Eigenvector } \\
\text { Centrality }\end{array}$ \\
\hline 17 & unlimited & 0.496529 & empower & 0.432385 \\
18 & global & 0.462316 & globe & 0.428513 \\
19 & value & 0.458485 & iconic & 0.428513 \\
20 & product & 0.427985 & inform & 0.428513 \\
21 & connect & 0.424779 & mind & 0.428513 \\
22 & society & 0.419977 & premier & 0.428513 \\
23 & lead & 0.391517 & reflect & 0.428513 \\
24 & people & 0.359082 & storytelling & 0.428513 \\
25 & contribute & 0.320346 & unparalleled & 0.428513 \\
26 & devote & 0.320346 & ambitious & 0.422212 \\
27 & service & 0.320346 & entrepreneur & 0.422212 \\
28 & superior & 0.320346 & flourish & 0.422212 \\
29 & frontier & 0.300195 & great & 0.422212 \\
30 & endeavor & 0.322167 & invest & 0.422212 \\
\hline
\end{tabular}

The main keywords of the top 100 Korean companies were "value," "company," "global," "customer," "lead," and "technology," and 30 keywords selected in the order of highest eigenvector centrality were mapped with the nine components as shown in Table A1 in the Appendix A. The main keywords of the top 100 US companies were "world," "customer," "people," "life," "innovation," and "improve," and 30 keywords selected in the order of highest eigenvector centrality were mapped with the nine components as shown in Table A2 in the Appendix A.

Among the top 100 Korean companies, the main keywords of the 79 Korean traditional companies were "value," "company," "global," "customer," "lead," and "growth," and 30 keywords selected in the order of highest eigenvector centrality were mapped with the nine components as shown in Table A3 in the Appendix A.

Among the top 100 US companies, the main keywords of the 66 US traditional companies were "world," "customer," "life," "innovation," "people," and "service," and 30 keywords selected in the order of highest eigenvector centrality were mapped with the nine components as shown in Table A4 in the Appendix A.

Among the top 100 Korean companies, the main keywords of the 21 innovative companies were "create," "future," "dream," "technology," "human," and "life," and 30 keywords selected in the order of highest eigenvector centrality were mapped with the nine components as shown in Table A5 in the Appendix A.

Among the top 100 US companies, the main keywords of the 34 innovative companies were "world," "people," "life," "company," "improve," and "innovation," and 30 keywords selected in the order of highest eigenvector centrality were mapped with the nine components as shown in Table A6 in the Appendix A.

\subsection{Second Network Analysis}

After mapping the keywords with the nine components of a mission statement, this study conducted a network analysis of the inclusion of the nine components in the mission statements of the top 100 Korean companies, top 100 US companies, Korean traditional companies, US traditional companies, Korean innovative companies, and US innovative companies, based on the matrix converted to a one-mode matrix. The size of the circles in the network analysis represents the order of eigenvector centrality. This study also separately analyzed the differences in component eigenvector centrality between the top 100 Korean and top 100 US companies, between Korean and US traditional companies, and between Korean and US innovative companies. A higher eigenvector centrality indicates a greater influence of network nodes, and thus components with high eigenvector centrality indicated the mission statement orientation aimed at by the group. 
The top 100 Korean companies had the highest orientation in product or service and concern for survival, and the lowest in concern for employees. In contrast, the top 100 US companies attached the greatest importance to philosophy. The differences are shown in Figure 3. The component with the second-highest eigenvector centrality of the top 100 US companies was products or services, which was similar to the result of the top 100 Korean companies. The top 100 US companies also showed relatively low eigenvector centrality in concern for employees, indicating that more direct elements such as philosophy, product, service, and survival were expressed with relatively higher importance than employees in the mission statements. Recently, environmental, social, and governance (ESG) has emerged as a key issue of corporate management in terms of sustainability, and an increasing number of companies are presenting separate ESG mission statements [53].

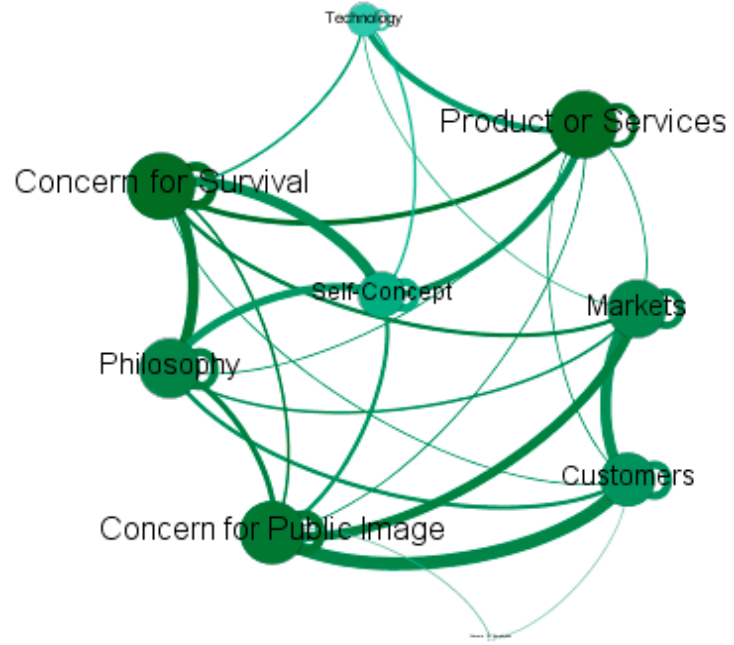

(a)

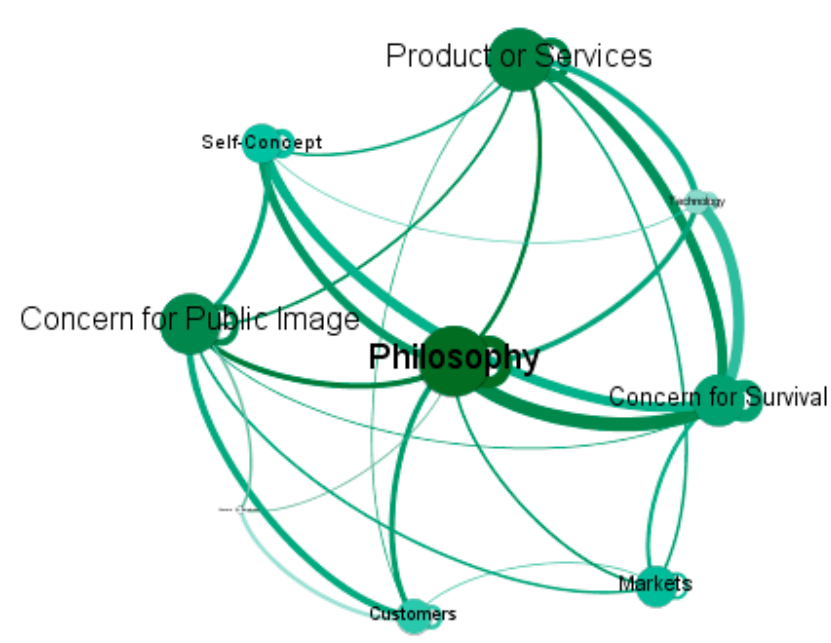

(b)

Figure 3. Network visualization of mission statement orientation by group (top 100 Korean companies vs. the top 100 US companies). (a) Top 100 Korean companies; (b) Top 100 US companies.

There was little difference in mission statement orientation between Korean traditional companies and the top 100 Korean companies. The mission statement orientation of US traditional companies was also similar to that of the top 100 US companies. Thus, the difference in orientation of the mission statement between Korean traditional companies and US traditional companies was similar to that between the top 100 Korean and top 100 US companies. However, the eigenvector centrality of self-concept of the mission statements of US traditional companies was higher than that of the mission statements of the top 100 US companies, as shown in Figure 4. 


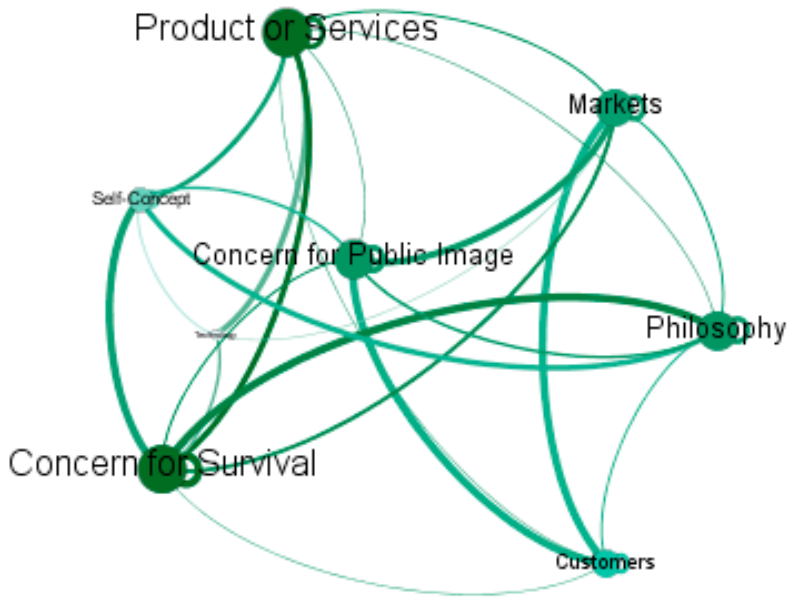

(a)

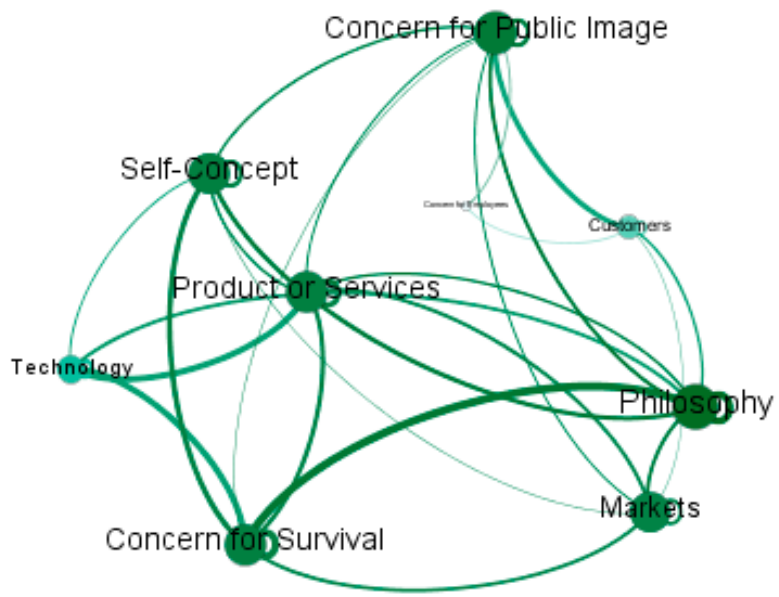

(b)

Figure 4. Network visualization of mission statement orientation by group (Korean traditional companies vs. US traditional companies). (a) Korean traditional companies; (b) US traditional companies.

The mission statements of innovative Korean companies were strongly oriented toward the philosophy component. US innovative companies also showed the highest eigenvector centrality for the philosophy component, similar to that of the top 100 US companies, indicating that the common orientation for mission statements in both Korean innovative companies and US innovative companies is toward the company philosophy. The differences are shown in Figure 5. Korean innovative companies showed equally high eigenvector centrality of self-concept as philosophy, which indicates that Korean innovative companies present their identities more clearly than Korean traditional companies for survival. Moreover, Korean innovative companies showed eigenvector centrality similar to that of traditional US companies. Figure 6 shows the results of the comparison of mission statement orientation, in terms of the nine components of a mission statement, among the groups of Korean and US companies.

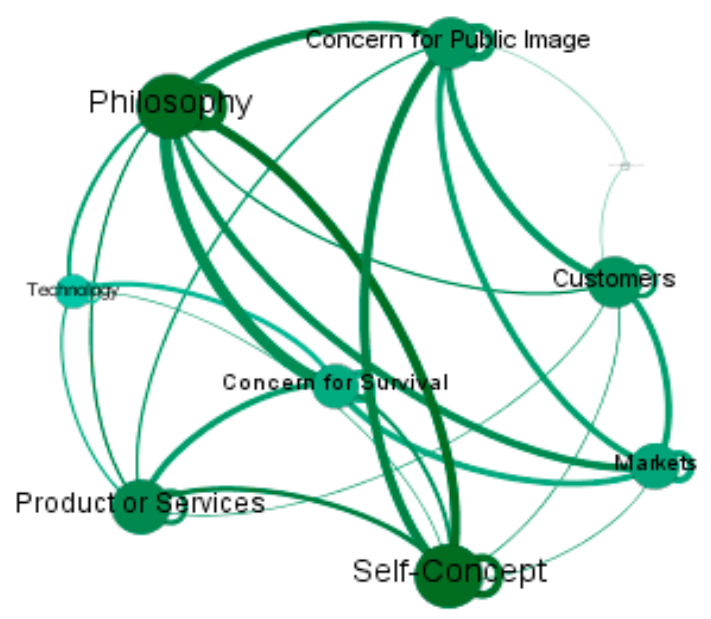

(a)

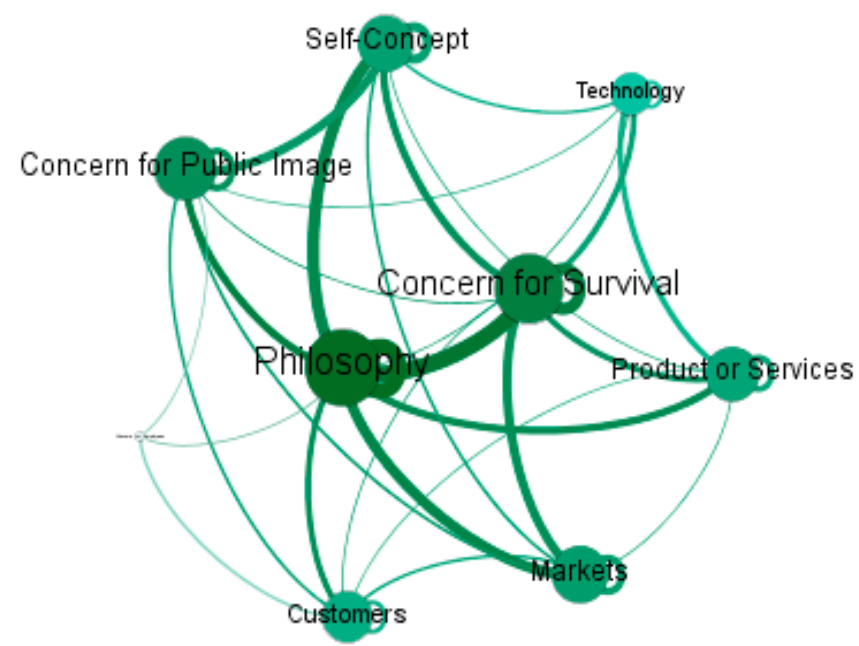

(b)

Figure 5. Network visualization of mission statement orientation by group (Korean innovative companies vs. US innovative companies). (a) Korean innovative companies; (b) US innovative companies. 


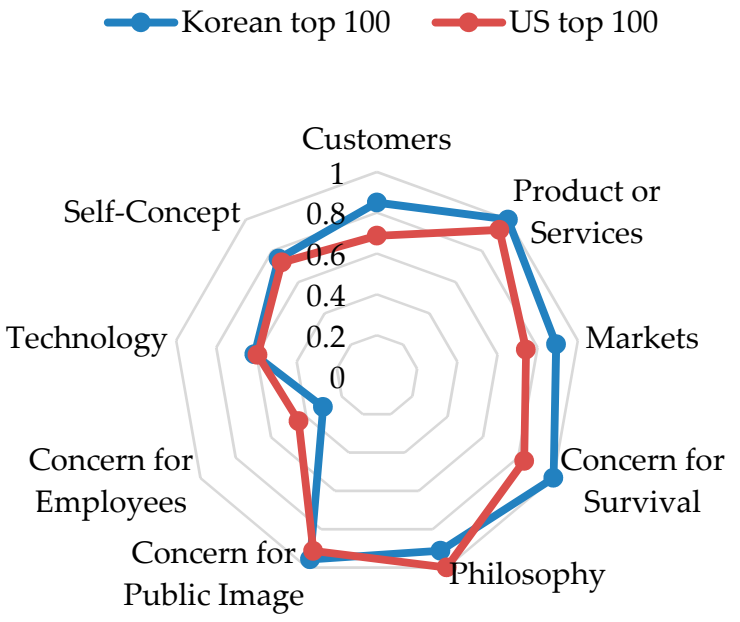

(a)

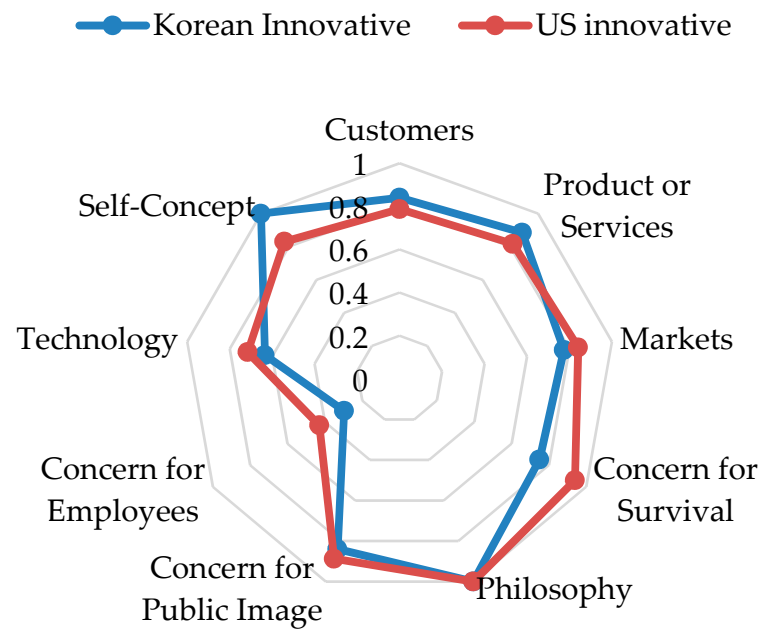

(b)

Figure 6. Comparison of mission statement orientation in terms of the nine components of a mission statement. (a) Top 100 Korean companies vs. top 100 US companies; (b) Korean innovative companies vs. US innovative companies.

\section{Discussion}

A company's mission statement conveys its aims and visions to the members of the organization, shareholders, and customers [1]. A mission statement reflects the first step of strategizing and expresses the reason for the company's existence, differentiating the company from its competitors [2,3]. Therefore, a mission statement is the most fundamental tool for implementing a company's strategies and the accomplishment of its goals. The sustainable growth of companies is becoming a major topic, and it has been found that mission statements are somewhat related to the innovation of companies [6]. Innovation is a key element of corporate performance, and an innovation-based perspective for competitive advantage leads to differentiated performance among companies [7].

This study comparatively analyzed the differences in the mission statement orientation of the top 100 Korean and top 100 US companies by market capitalization. For the analysis, the websites of the top 100 Korean and top 100 US companies by market capitalization were checked to summarize their mission statements and to categorize the companies as either traditional or innovative. The readability of mission statements was assessed and compared using the GFI. Keywords were extracted using the text-mining tool R, and a social network analysis was conducted using Gephi software. The nine components of a mission statement were used to analyze the differences in mission statement orientation of Korean and US companies [19]. The extracted keywords were mapped to identify the component to which they belonged, and the orientation was determined based on eigenvector centrality [51,52].

There was no significant difference between Korean and US companies in terms of readability of mission statements. However, there was a significant difference in readability between traditional and innovative companies in both Korea and the United States. The readability of mission statements of innovative companies was better than that of traditional companies, which indicates that the mission statements of innovative companies in both Korea and the United States were relatively more concise and easier to understand than those of traditional companies. Communication between stakeholders and employees is important for companies to produce results. For constant innovation, mission statements must be readable and easily understood by all stakeholders [2].

Results of the keyword analysis revealed significant differences between Korean and US companies. The top 100 Korean companies frequently used the word "global" and aimed to be leading companies that provided value to customers, whereas the top 100 US companies expressed the goal of providing innovation in products and services 
for customers throughout the world. There was also a difference in keywords between the Korean and US innovative companies. Korean innovative companies showed high eigenvector centrality in keywords such as "create," "future," and "dream," indicating that their mission was to fulfill future dreams using creativity based on technology and focused on people, whereas US innovative companies showed similar keywords and eigenvector centrality as the top 100 US companies and US traditional companies. This suggests that the top 100 US companies by market capitalization mostly have the attributes of innovative companies and are already acknowledged in the market as sustainable companies.

In the orientation analysis by country and group, the mapping of the nine components and keywords showed that the mission statements of the top 100 Korean companies were oriented toward products or services and concern for survival. The top 100 US companies gave top priority to their philosophy. The mission statement orientation of Korean traditional companies was not significantly different from that of the top 100 Korean companies. Korean innovative companies showed the highest eigenvector centrality for the philosophy component. US innovative companies also showed the highest eigenvector centrality for the philosophy component, similar to that of the top 100 US companies, indicating that the common mission statement orientation of Korean and US innovative companies is philosophy. Korean innovative companies showed a high eigenvector centrality of self-concept, similar to philosophy, which indicates that Korean innovative companies are presenting their identities more clearly than Korean traditional companies for survival. Moreover, Korean innovative companies showed similar eigenvector centrality to traditional US companies.

\section{Conclusions}

This study has significance in that it compares mission statements of Korean and US companies; the mission statements reflect the goals pursued by the companies and the reasons for the existence of the companies. This study also analyzed the differences in the orientation of the mission statements.

Many researchers have analyzed the mission statements of countries [12-14]. However, there were no cases in which the differences in mission statements of Korean and US companies were analyzed. There is a great difference in market capitalization between Korean and US companies, but Korea has the world's highest innovation index [16]. Therefore, the significance of this study is in the fact that it selected the subjects of analysis based on the market capitalization of the countries and analyzed the orientation of Korean and US innovative companies.

Moreover, nine components of a mission statement were examined through a keyword network analysis to determine the difference between Korean and US companies, which is also a novel attempt. However, further analysis is necessary to determine whether there is a correlation between corporate performance and mission statement readability. The subjects were also limited to the top 100 companies by market capitalization in Korea and the United States. Future research should examine the differences in mission statement orientation among unicorn companies with high growth potential.

ESG has recently emerged as a key issue in management, and many studies have been conducted on ESG management and corporate performance. However, there is still controversy over whether there is a clear correlation between ESG management and corporate performance [54]. A mission statement is a tool that expresses the reason for a company's existence and serves as a channel of communication between the company and stakeholders [1-3]. As the business environment changes over time, continuous research is needed on how to reflect and develop issues such as ESG in mission statements.

Author Contributions: Conceptualization, J.J.; methodology, J.J.; software, J.J.; validation, K.T.C.; formal analysis, J.J.; writing — original draft preparation, J.J.; writing-review and editing, J.J. and K.T.C.; supervision, K.T.C. Both authors have read and agreed to the published version of the manuscript.

Funding: This research received no external funding. 
Institutional Review Board Statement: Not applicable.

Informed Consent Statement: Not applicable.

Data Availability Statement: Not applicable.

Conflicts of Interest: The authors declare no conflict of interest.

\section{Appendix A}

Table A1. Thirty keywords mapped with nine components-top 100 Korean companies.

\begin{tabular}{cccccccccc}
\hline Word & A & B & C & D & E & F & G & H & I \\
\hline value & 1 & 1 & 0 & 0 & 0 & 1 & 0 & 0 & 0 \\
company & 0 & 0 & 0 & 0 & 1 & 1 & 1 & 0 & 0 \\
global & 0 & 0 & 1 & 0 & 1 & 1 & 0 & 0 & 0 \\
customer & 1 & 0 & 1 & 0 & 0 & 0 & 0 & 1 & 0 \\
lead & 0 & 0 & 1 & 0 & 1 & 1 & 0 & 0 & 0 \\
technology & 0 & 1 & 0 & 1 & 1 & 0 & 0 & 0 & 0 \\
life & 0 & 0 & 0 & 0 & 0 & 1 & 1 & 1 & 0 \\
growth & 0 & 0 & 0 & 0 & 1 & 1 & 1 & 0 & 0 \\
create & 0 & 1 & 0 & 1 & 1 & 0 & 0 & 0 & 0 \\
society & 1 & 0 & 1 & 0 & 0 & 0 & 0 & 1 & 0 \\
contribute & 1 & 0 & 1 & 0 & 0 & 0 & 0 & 1 & 0 \\
business & 0 & 0 & 0 & 0 & 1 & 1 & 1 & 0 & 0 \\
trust & 1 & 0 & 0 & 0 & 0 & 1 & 0 & 1 & 0 \\
develop & 0 & 1 & 0 & 1 & 0 & 0 & 1 & 0 & 0 \\
service & 0 & 1 & 0 & 0 & 0 & 0 & 1 & 1 & 0 \\
product & 0 & 1 & 0 & 0 & 1 & 0 & 1 & 0 & 0 \\
future & 0 & 1 & 0 & 0 & 1 & 0 & 1 & 0 & 0 \\
industry & 0 & 1 & 1 & 1 & 0 & 0 & 0 & 0 & 0 \\
continue & 0 & 0 & 0 & 0 & 1 & 1 & 1 & 0 & 0 \\
social & 1 & 0 & 1 & 0 & 0 & 0 & 0 & 1 & 0 \\
responsibility & 1 & 0 & 1 & 0 & 0 & 0 & 0 & 1 & 0 \\
corporate & 1 & 0 & 1 & 0 & 0 & 0 & 0 & 1 & 0 \\
ecofriendly & 0 & 0 & 0 & 0 & 1 & 1 & 0 & 1 & 0 \\
human & 1 & 0 & 0 & 0 & 0 & 1 & 0 & 1 & 0 \\
management & 0 & 0 & 0 & 0 & 1 & 1 & 1 & 0 & 0 \\
happy & 1 & 0 & 0 & 0 & 0 & 0 & 0 & 1 & 1 \\
energy & 0 & 1 & 0 & 1 & 0 & 0 & 1 & 0 & 0 \\
sustainable & 1 & 0 & 1 & 0 & 0 & 0 & 0 & 1 & 0 \\
community & 0 & 0 & 0 & 0 & 1 & 0 & 1 & 1 & 0 \\
local & 1 & 0 & 1 & 0 & 1 & 0 & 0 & 0 & 0 \\
\hline & & & & & & & & & \\
\hline
\end{tabular}

Table A2. Thirty keywords mapped with nine components-top 100 US companies.

\begin{tabular}{cccccccccc}
\hline Word & A & B & C & D & E & F & G & H & I \\
\hline world & 0 & 0 & 1 & 0 & 1 & 1 & 0 & 0 & 0 \\
customer & 1 & 0 & 1 & 0 & 0 & 0 & 0 & 1 & 0 \\
people & 1 & 0 & 0 & 0 & 0 & 0 & 0 & 1 & 1 \\
life & 0 & 0 & 0 & 0 & 0 & 1 & 1 & 1 & 0 \\
innovation & 0 & 1 & 0 & 1 & 1 & 0 & 0 & 0 & 0 \\
improve & 0 & 0 & 0 & 1 & 1 & 0 & 1 & 0 & 0 \\
company & 0 & 0 & 0 & 0 & 1 & 1 & 1 & 0 & 0 \\
service & 0 & 1 & 0 & 0 & 0 & 0 & 1 & 1 & 0 \\
create & 0 & 1 & 0 & 1 & 1 & 0 & 0 & 0 & 0 \\
technology & 0 & 1 & 0 & 1 & 1 & 0 & 0 & 0 & 0 \\
way & 0 & 0 & 0 & 0 & 1 & 1 & 1 & 0 & 0 \\
finance & 0 & 1 & 1 & 0 & 1 & 0 & 0 & 0 & 0
\end{tabular}


Table A2. Cont.

\begin{tabular}{cccccccccc}
\hline Word & A & B & C & D & E & F & G & H & I \\
\hline advance & 0 & 0 & 0 & 1 & 1 & 1 & 0 & 0 & 0 \\
value & 1 & 1 & 0 & 0 & 0 & 1 & 0 & 0 & 0 \\
business & 0 & 0 & 0 & 0 & 1 & 1 & 1 & 0 & 0 \\
product & 0 & 1 & 0 & 0 & 1 & 0 & 1 & 0 & 0 \\
community & 0 & 0 & 0 & 0 & 1 & 0 & 1 & 1 & 0 \\
growth & 0 & 0 & 0 & 0 & 1 & 1 & 1 & 0 & 0 \\
solution & 0 & 1 & 0 & 1 & 0 & 1 & 0 & 0 & 0 \\
economy & 0 & 1 & 1 & 0 & 0 & 0 & 0 & 1 & 0 \\
live & 1 & 0 & 0 & 0 & 0 & 1 & 0 & 1 & 0 \\
connect & 0 & 0 & 0 & 1 & 1 & 1 & 0 & 0 & 0 \\
time & 0 & 0 & 0 & 0 & 0 & 1 & 1 & 1 & 0 \\
invest & 0 & 1 & 0 & 0 & 1 & 1 & 0 & 0 & 0 \\
challenge & 0 & 0 & 1 & 0 & 1 & 1 & 0 & 0 & 0 \\
together & 1 & 0 & 0 & 0 & 0 & 0 & 0 & 1 & 1 \\
human & 1 & 0 & 0 & 0 & 0 & 1 & 0 & 1 & 0 \\
experience & 0 & 0 & 0 & 1 & 1 & 1 & 0 & 0 & 0
\end{tabular}

Table A3. Thirty keywords mapped with nine components-Korean traditional companies.

\begin{tabular}{cccccccccc}
\hline Word & A & B & C & D & E & F & G & H & I \\
\hline value & 1 & 1 & 0 & 0 & 0 & 1 & 0 & 0 & 0 \\
company & 0 & 0 & 0 & 0 & 1 & 1 & 1 & 0 & 0 \\
global & 0 & 0 & 1 & 0 & 1 & 1 & 0 & 0 & 0 \\
customer & 1 & 0 & 1 & 0 & 0 & 0 & 0 & 1 & 0 \\
lead & 0 & 0 & 1 & 0 & 1 & 1 & 0 & 0 & 0 \\
growth & 0 & 0 & 0 & 0 & 1 & 1 & 1 & 0 & 0 \\
business & 0 & 0 & 0 & 0 & 1 & 1 & 1 & 0 & 0 \\
life & 0 & 0 & 0 & 0 & 0 & 1 & 1 & 1 & 0 \\
technology & 0 & 1 & 0 & 1 & 1 & 0 & 0 & 0 & 0 \\
create & 0 & 1 & 0 & 1 & 1 & 0 & 0 & 0 & 0 \\
contribute & 1 & 0 & 1 & 0 & 0 & 0 & 0 & 1 & 0 \\
service & 0 & 1 & 0 & 0 & 0 & 0 & 1 & 1 & 0 \\
develop & 0 & 1 & 0 & 1 & 0 & 0 & 1 & 0 & 0 \\
industry & 0 & 1 & 1 & 1 & 0 & 0 & 0 & 0 & 0 \\
trust & 1 & 0 & 0 & 0 & 0 & 1 & 0 & 1 & 0 \\
continue & 0 & 0 & 0 & 0 & 1 & 1 & 1 & 0 & 0 \\
product & 0 & 1 & 0 & 0 & 1 & 0 & 1 & 0 & 0 \\
society & 1 & 0 & 1 & 0 & 0 & 0 & 0 & 1 & 0 \\
social & 1 & 0 & 1 & 0 & 0 & 0 & 0 & 1 & 0 \\
ecofriendly & 0 & 0 & 0 & 0 & 1 & 1 & 0 & 1 & 0 \\
corporate & 1 & 0 & 1 & 0 & 0 & 0 & 0 & 1 & 0 \\
management & 0 & 0 & 0 & 0 & 1 & 1 & 1 & 0 & 0 \\
energy & 0 & 1 & 0 & 1 & 0 & 0 & 1 & 0 & 0 \\
sustainable & 1 & 0 & 1 & 0 & 0 & 0 & 0 & 1 & 0 \\
future & 0 & 1 & 0 & 0 & 1 & 0 & 1 & 0 & 0 \\
community & 0 & 0 & 0 & 0 & 1 & 0 & 1 & 1 & 0 \\
local & 1 & 0 & 1 & 0 & 1 & 0 & 0 & 0 & 0 \\
responsibility & 1 & 0 & 1 & 0 & 0 & 0 & 0 & 1 & 0 \\
competitive & 0 & 1 & 1 & 0 & 1 & 0 & 0 & 0 & 0 \\
high & 0 & 1 & 0 & 1 & 1 & 0 & 0 & 0 & 0 \\
\hline & & & & & & & & & \\
& 0 & 0 & 0 & 0 & 0 \\
\end{tabular}


Table A4. Thirty keywords mapped with nine components-US traditional companies.

\begin{tabular}{cccccccccc}
\hline Word & A & B & C & $\mathbf{D}$ & $\mathbf{E}$ & $\mathbf{F}$ & $\mathbf{G}$ & $\mathbf{H}$ & $\mathbf{I}$ \\
\hline world & 0 & 0 & 1 & 0 & 1 & 1 & 0 & 0 & 0 \\
customer & 1 & 0 & 1 & 0 & 0 & 0 & 0 & 1 & 0 \\
life & 0 & 0 & 0 & 0 & 0 & 1 & 1 & 1 & 0 \\
innovation & 0 & 1 & 0 & 1 & 1 & 0 & 0 & 0 & 0 \\
people & 1 & 0 & 0 & 0 & 0 & 0 & 0 & 1 & 1 \\
service & 0 & 1 & 0 & 0 & 0 & 0 & 1 & 1 & 0 \\
way & 0 & 0 & 0 & 0 & 1 & 1 & 1 & 0 & 0 \\
company & 0 & 0 & 0 & 0 & 1 & 1 & 1 & 0 & 0 \\
business & 0 & 0 & 0 & 0 & 1 & 1 & 1 & 0 & 0 \\
improve & 0 & 0 & 0 & 1 & 1 & 0 & 1 & 0 & 0 \\
advance & 0 & 0 & 0 & 1 & 1 & 1 & 0 & 0 & 0 \\
finance & 0 & 1 & 1 & 0 & 1 & 0 & 0 & 0 & 0 \\
solution & 0 & 1 & 0 & 1 & 0 & 1 & 0 & 0 & 0 \\
live & 1 & 0 & 0 & 0 & 0 & 1 & 0 & 1 & 0 \\
create & 0 & 1 & 0 & 1 & 1 & 0 & 0 & 0 & 0 \\
technology & 0 & 1 & 0 & 1 & 1 & 0 & 0 & 0 & 0 \\
growth & 0 & 0 & 0 & 0 & 1 & 1 & 1 & 0 & 0 \\
human & 1 & 0 & 0 & 0 & 0 & 1 & 0 & 1 & 0 \\
community & 0 & 0 & 0 & 0 & 1 & 0 & 1 & 1 & 0 \\
together & 1 & 0 & 0 & 0 & 0 & 0 & 0 & 1 & 1 \\
lead & 0 & 0 & 1 & 0 & 1 & 1 & 0 & 0 & 0 \\
communicate & 1 & 0 & 0 & 0 & 0 & 1 & 0 & 1 & 0 \\
challenge & 0 & 0 & 1 & 0 & 1 & 1 & 0 & 0 & 0 \\
better & 0 & 1 & 0 & 1 & 1 & 0 & 0 & 0 & 0 \\
solve & 0 & 1 & 0 & 1 & 0 & 1 & 0 & 0 & 0 \\
full & 0 & 1 & 1 & 0 & 0 & 1 & 0 & 0 & 0 \\
range & 0 & 1 & 1 & 0 & 0 & 0 & 1 & 0 & 0 \\
connect & 0 & 0 & 0 & 1 & 1 & 1 & 0 & 0 & 0 \\
economy & 0 & 1 & 1 & 0 & 0 & 0 & 0 & 1 & 0 \\
science & 0 & 1 & 0 & 1 & 0 & 0 & 1 & 0 & 0 \\
\hline & & & & & & & & & \\
\hline
\end{tabular}

Table A5. Thirty keywords mapped with nine components-Korean innovative companies.

\begin{tabular}{cccccccccc}
\hline Keyword & A & B & C & D & E & F & G & H & I \\
\hline create & 0 & 1 & 0 & 1 & 1 & 0 & 0 & 0 & 0 \\
future & 0 & 1 & 0 & 0 & 1 & 0 & 1 & 0 & 0 \\
dream & 0 & 0 & 0 & 0 & 0 & 1 & 1 & 1 & 0 \\
technology & 0 & 1 & 0 & 1 & 1 & 0 & 0 & 0 & 0 \\
human & 1 & 0 & 0 & 0 & 0 & 1 & 0 & 1 & 0 \\
life & 0 & 0 & 0 & 0 & 0 & 1 & 1 & 1 & 0 \\
realize & 0 & 0 & 0 & 1 & 1 & 1 & 0 & 0 & 0 \\
thinking & 0 & 0 & 0 & 1 & 0 & 1 & 1 & 0 & 0 \\
challenge & 0 & 0 & 1 & 0 & 1 & 1 & 0 & 0 & 0 \\
mankind & 1 & 0 & 1 & 0 & 0 & 0 & 0 & 1 & 0 \\
world & 0 & 0 & 1 & 0 & 1 & 1 & 0 & 0 & 0 \\
building & 0 & 1 & 0 & 0 & 1 & 1 & 0 & 0 & 0 \\
possibility & 0 & 0 & 0 & 0 & 0 & 1 & 1 & 1 & 0 \\
responsibility & 1 & 0 & 1 & 0 & 0 & 0 & 0 & 1 & 0 \\
sense & 1 & 0 & 1 & 0 & 0 & 0 & 1 & 0 & 0 \\
tackling & 0 & 0 & 1 & 0 & 1 & 1 & 0 & 0 & 0 \\
unlimited & 0 & 0 & 0 & 0 & 0 & 1 & 1 & 1 & 0 \\
global & 0 & 0 & 1 & 0 & 1 & 1 & 0 & 0 & 0 \\
value & 1 & 1 & 0 & 0 & 0 & 1 & 0 & 0 & 0 \\
product & 0 & 1 & 0 & 0 & 1 & 0 & 1 & 0 & 0 \\
connect & 0 & 0 & 0 & 1 & 1 & 1 & 0 & 0 & 0 \\
society & 1 & 0 & 1 & 0 & 0 & 0 & 0 & 1 & 0 \\
\hline
\end{tabular}


Table A5. Cont.

\begin{tabular}{cccccccccc}
\hline Keyword & A & B & C & D & E & F & G & H & I \\
\hline lead & 0 & 0 & 1 & 0 & 1 & 1 & 0 & 0 & 0 \\
people & 1 & 0 & 0 & 0 & 0 & 0 & 0 & 1 & 1 \\
contribute & 1 & 0 & 1 & 0 & 0 & 0 & 0 & 1 & 0 \\
devote & 0 & 0 & 0 & 0 & 0 & 1 & 1 & 1 & 0 \\
service & 0 & 1 & 0 & 0 & 0 & 0 & 1 & 1 & 0 \\
superior & 0 & 1 & 0 & 0 & 0 & 0 & 1 & 1 & 0 \\
frontier & 0 & 0 & 1 & 0 & 0 & 1 & 0 & 1 & 0 \\
endeavor & 0 & 0 & 0 & 0 & 1 & 1 & 1 & 0 & 0 \\
\hline
\end{tabular}

Table A6. Thirty keywords mapped with nine components-US innovative companies.

\begin{tabular}{cccccccccc}
\hline Keyword & A & B & C & D & E & F & G & H & I \\
\hline world & 0 & 0 & 1 & 0 & 1 & 1 & 0 & 0 & 0 \\
people & 1 & 0 & 0 & 0 & 0 & 0 & 0 & 1 & 1 \\
life & 0 & 0 & 0 & 0 & 0 & 1 & 1 & 1 & 0 \\
company & 0 & 0 & 0 & 0 & 1 & 1 & 1 & 0 & 0 \\
improve & 0 & 0 & 0 & 1 & 1 & 0 & 1 & 0 & 0 \\
innovation & 0 & 1 & 0 & 1 & 1 & 0 & 0 & 0 & 0 \\
brand & 0 & 0 & 1 & 0 & 0 & 0 & 1 & 1 & 0 \\
thing & 0 & 1 & 0 & 1 & 0 & 1 & 0 & 0 & 0 \\
create & 0 & 1 & 0 & 1 & 1 & 0 & 0 & 0 & 0 \\
power & 0 & 0 & 1 & 0 & 1 & 0 & 1 & 0 & 0 \\
opportunity & 0 & 0 & 1 & 0 & 1 & 1 & 0 & 0 & 0 \\
customer & 1 & 0 & 1 & 0 & 0 & 0 & 0 & 1 & 0 \\
entertain & 0 & 1 & 1 & 0 & 0 & 1 & 0 & 0 & 0 \\
technology & 0 & 1 & 0 & 1 & 1 & 0 & 0 & 0 & 0 \\
inspire & 1 & 0 & 1 & 0 & 0 & 1 & 0 & 0 & 0 \\
value & 1 & 1 & 0 & 0 & 0 & 1 & 0 & 0 & 0 \\
empower & 1 & 0 & 0 & 0 & 0 & 1 & 0 & 0 & 1 \\
globe & 0 & 0 & 1 & 0 & 1 & 1 & 0 & 0 & 0 \\
iconic & 0 & 0 & 0 & 0 & 0 & 1 & 1 & 1 & 0 \\
inform & 0 & 0 & 0 & 0 & 1 & 1 & 1 & 0 & 0 \\
mind & 0 & 0 & 0 & 0 & 1 & 1 & 1 & 0 & 0 \\
premier & 0 & 0 & 0 & 0 & 0 & 1 & 1 & 1 & 0 \\
reflect & 1 & 0 & 0 & 0 & 1 & 1 & 0 & 0 & 0 \\
storytelling & 0 & 1 & 0 & 0 & 0 & 1 & 1 & 0 & 0 \\
unparalleled & 0 & 0 & 0 & 1 & 0 & 0 & 1 & 1 & 0 \\
ambitious & 0 & 0 & 1 & 0 & 1 & 1 & 0 & 0 & 0 \\
entrepreneur & 0 & 0 & 0 & 0 & 1 & 1 & 0 & 1 & 0 \\
flourish & 0 & 0 & 1 & 0 & 1 & 1 & 0 & 0 & 0 \\
great & 0 & 0 & 0 & 0 & 0 & 1 & 1 & 1 & 0 \\
invest & 0 & 1 & 0 & 0 & 1 & 1 & 0 & 0 & 0 \\
\hline & & & & & & & & & \\
& 0 & 0 & 0 & 0 & 0 & 0 \\
\end{tabular}

\section{References}

1. Leuthesser, L.; Kohli, C. Corporate identity: The role of mission statements. Bus. Horiz. 1997, 40, 59-66. [CrossRef]

2. Pearce, J.A., II. The company mission as a strategic tool. Sloan Manag. Rev. 1982, 23, 15.

3. Pearce, J.A.; David, F. Corporate mission statements: The bottom line. Acad. Manag. Perspect. 1987, 1, 109-115. [CrossRef]

4. Drucker, P.F. Tasks, Responsibilities, Practices; Harper \& Row: New York, NY, USA, 1974; p. 61.

5. Rajasekar, J. A comparative analysis of mission statement content and readability. J. Manag. Policy Pract. 2013, 14, $131-147$.

6. Zhang, H.; Garrett, T.; Liang, X. The effects of innovation-oriented mission statements on innovation performance and nonfinancial business performance. Asian J. Technol. Innov. 2015, 23, 157-171. [CrossRef]

7. Hossain, M. Business model innovation: Past research, current debates, and future directions. J. Strategy Manag. 2017, 10, $342-359$. [CrossRef]

8. Dobni, C.B.; Klassen, M.; Nelson, W.T. Innovation strategy in the US: Top executives offer their views. J. Bus. Strategy 2015, 36, 3-13. [CrossRef]

9. Lichtenthaler, U. The world's most innovative companies: A meta-ranking. J. Strategy Manag. 2018, 11, 497-511. [CrossRef] 
10. Leslie, K.; Melissa, K. You Call That Innovation? Wall Street J. 2012, 59, B1-B8. Available online: https://www.wsj.com/articles/ SB10001424052702304791704577418250902309914 (accessed on 12 June 2021).

11. Alegre, I.; Berbegal-Mirabent, J.; Guerrero, A.; Mas-Machuca, M. The real mission of the mission statement: A systematic review of the literature. J. Manag. Organ. 2018, 24, 456-473. [CrossRef]

12. Bartkus, B.R.; Glassman, M.; McAfee, R.B. A comparison of the quality of european, japanese and us mission statements: A content analysis. Eur. Manag. J. 2004, 22, 393-401. [CrossRef]

13. Lin, Q.; Huang, Y.; Zhu, R.; Zhang, Y. Comparative Analysis of Mission Statements of Chinese and American Fortune 500 Companies: A Study from the Perspective of Linguistics. Sustainability 2019, 11, 4905. [CrossRef]

14. Yadav, N.; Sehgal, V. India's Super 50 companies and their mission statement: A multifold perspective. J. Strategy Manag. 2019, 12, 208-226. [CrossRef]

15. Media, F. Investing.com. Available online: https://kr.investing.com/stock-screener/ (accessed on 20 April 2021).

16. Michelle Jamrisko, W.L.; Alexandre, T. South Korea Leads World in Innovation as U.S. Exits Top Ten. Available online: https: / / www.bloomberg.com/news/articles/2021-02-03/south-korea-leads-world-in-innovation-u-s-drops-out-of-top-10 (accessed on 12 July 2021).

17. Radtke, J.M. How to write a mission statement. Grantsmansh. Cent. Mag. 1998, 68, 1-3.

18. Bart, C.K. Mission matters. CPA J. 1998, 68, 31-33.

19. David, F.R. How companies define their mission. Long Range Plan. 1989, 22, 90-97. [CrossRef]

20. Rey, C.; Bastons, M. Three dimensions of effective mission implementation. Long Range Plan. 2018, 51, 580-585. [CrossRef]

21. Berbegal-Mirabent, J.; Mas-Machuca, M.; Guix, P. Impact of mission statement components on social enterprises' performance. Rev. Manag. Sci. 2021, 15, 705-724. [CrossRef]

22. Kemp, S.; Dwyer, L. Mission statements of international airlines: A content analysis. Tour. Manag. 2003, 24, 635-653. [CrossRef]

23. Lin, Y.H.; Ryan, C.; Wise, N.; Low, L.W. A content analysis of airline mission statements: Changing trends and contemporary components. Tour. Manag. Perspect. 2018, 28, 156-165. [CrossRef]

24. Drucker, P.F. Managing the Non-Profit Organization: Practices and Principles; Taylor \& Francis: Abingdon, UK, 1995.

25. Arias-Coello, A.; Simon-Martin, J.; Gonzalo Sanchez-Molero, J.L. Mission statements in Spanish universities. Stud. High. Educ. 2020, 45, 299-311. [CrossRef]

26. Ireland, R.D.; Hirc, M.A. Mission statements: Importance, challenge, and recommendations for development. Bus. Horiz. 1992, 35, 34-42. [CrossRef]

27. Bart Baetz, C.K.; Mark, C. The relationship between mission statements and firm performance: An exploratory study. J. Manag. Stud. 1998, 35, 823-853. [CrossRef]

28. Atrill, P.; Omran, M.; Pointon, J. Company mission statements and financial performance. Corp. Ownersh. Control. 2005, 2, 28-35. [CrossRef]

29. Gunning, R. The fog index after twenty years. J. Bus. Commun. 1969, 6, 3-13. [CrossRef]

30. Khan, M.K.; Bhatti, G.A.; Ahmed, I.; Islam, T. Readability and Understandability: A look at mission statements of selected asian companies. J. Res. Soc. Pak. -Vol. 2017, 54, 123-135.

31. Cortes, J.D.; Rivera, L.; Carbonell, K.B. Mission Statements in Universities: Readability and performance. arXiv 2021, arXiv:2104.07438.

32. Cortés-Sánchez, J.D.; Rivera, L. Mission statements and financial performance in Latin-American firms. Bus. Theory Pract. 2019, 20, 270-283. [CrossRef]

33. Li, F. Annual report readability, current earnings, and earnings persistence. J. Account. Econ. 2008, 45, 221-247. [CrossRef]

34. Bart, C.K. High tech firms: Does mission matter? J. High Technol. Manag. Res. 1996, 7, 209-225. [CrossRef]

35. Bart, C. Innovation, mission statements and learning. Int. J. Technol. Manag. 2004, 27, 544-561. [CrossRef]

36. Covin, J.G.; Prescott, J.E. Strategies, styles, and structures of small product innovative firms in high and low technology industries. J. High Technol. Manag. Res. 1990, 1, 39-56. [CrossRef]

37. Bayrak, T. A content analysis of top-ranked universities' mission statements from five global regions. Int. J. Educ. Dev. 2020, 72, 102-130. [CrossRef]

38. Guimarães, F.F.; Finardi, K.R.; El Kadri, M.S.; Taquini, R. The mission statements of the federal universities and the projection of internationalization in Brazil. System 2020, 94, 102331. [CrossRef]

39. Law, K.M.; Breznik, K. What do airline mission statements reveal about value and strategy? J. Air Transp. Manag. 2018, 70, 36-44. [CrossRef]

40. Penco, L.; Profumo, G.; Scarsi, R. Stakeholder Orientation in Cruise Lines' Mission Statements. Sustainability 2017,9 , 2151. [CrossRef]

41. Boston Consulting Group. Overcoming the Innovation Readiness Gap. Available online: https://www.bcg.com/publications/20 21/most-innovative-companies-overview (accessed on 20 April 2021).

42. Forbes. The World's Most Innovative Companies. Available online: https://www.forbes.com/innovative-companies/list/\#tab: rank (accessed on 20 April 2021).

43. Clarivate. Celebrating 10 Years of the Top 100 Global Innovators. Available online: https://clarivate.com/top-100-innovators/ (accessed on 20 April 2021). 
44. Fnguide. FnGuide K-Innovation Indices. Available online: http://www.fnindex.co.kr/overview/detail/C/FI00.WLT.SKI (accessed on 20 April 2021).

45. Exchange of Korea. K-BBIG Index. Available online: http://data.krx.co.kr/contents/MDC/MDI/mdiLoader/index.cmd? menuId=MDC0201010101 (accessed on 21 April 2021).

46. Feinerer, I. An introduction to text mining in R. R News 2008, 8, 19-22.

47. Bastian, M.; Heymann, S.; Jacomy, M. Gephi: An open source software for exploring and manipulating networks. In Proceedings of the Third international AAAI Conference on Weblogs and Social Media, San Jose, CA, USA, 17-20 May 2009.

48. Huisman, M.; Van Duijn, M.A. Software for social network analysis. Models Methods Soc. Netw. Anal. 2005,270 , e316.

49. Lee, S.-S. A content analysis of journal articles using the language network analysis methods. J. Korean Soc. Inf. Manag. 2014, 31, 49-68.

50. Freeman, L.C. Centrality in social networks conceptual clarification. Soc. Netw. 1978, 1, 215-239. [CrossRef]

51. Bonacich, P. Some unique properties of eigenvector centrality. Soc. Netw. 2007, 29, 555-564. [CrossRef]

52. Choi, Y.G.; Cho, K.T. Analysis of Safety Management Characteristics Using Network Analysis of CEO Messages in the Construction Industry. Sustainability 2020, 12, 5771. [CrossRef]

53. Zumente, I.; Bistrova, J. ESG Importance for Long-Term Shareholder Value Creation: Literature vs. Practice. J. Open Innov. Technol. Mark. Complex. 2021, 7, 127. [CrossRef]

54. Nirino, N.; Santoro, G.; Miglietta, N.; Quaglia, R. Corporate controversies and company's financial performance: Exploring the moderating role of ESG practices. Technol. Forecast. Soc. Chang. 2021, 162, 120341. [CrossRef] 